\title{
MODELLING OF DAILY ACTIVITY SCHEDULE OF WORKERS USING UNSUPERVISED MACHINE LEARNING TECHNIQUE
}

\author{
Anu P. Alex ${ }^{1}$, Manju V. Saraswathy ${ }^{2}$, Kuncheria P. Isaac ${ }^{3}$ \\ ${ }^{1,2}$ The College of Engineering Trivandrum, Kerala, India \\ ${ }^{3}$ APJ Abdul Kalam Technological University Kerala, India
}

Received 13 November 2015; accepted 12 February 2016

\begin{abstract}
Travel demand models are used to replicate the real world travel demand and to predict the future travel demand. A behavioural oriented approach in travel demand analysis is provided by activity based travel demand modelling and it provides a better understanding of the travel behaviour of an individual. A sequential modelling approach using econometric models is commonly used in activity based travel modelling. In this method, error obtained in one model will be carried forward to the second model and so on. Hence chances of accumulation of error are more at the final stage, when the models are used for prediction. Hence an attempt is made in this study to replace the sequential econometric modelling approach with simultaneous modelling approach using an unsupervised machine learning technique. Three stage Neural Network modelling used in this study replaces sixteen stage econometric models. The predictive accuracy of all the output parameters was compared in both the modelling approaches. Results shows that Artificial Neural Network (ANN) results outperform econometric models. The decrease in percentage error ranges from $2.22 \%$ to $27.17 \%$.
\end{abstract}

Keywords: work activity, ANN, econometric models.

\section{Introduction}

Travel demand modelling is an essential tool in transportation planning. Traditional trip based travel demand models are successfully replaced by superior and advanced activity based travel demand modelling in various countries. This is due to its capability in modelling the time and sequence of activities as well as the competence of incorporating the behaviour of individuals. Activity based travel demand models are based on the renowned notion that 'travel is derived from demand to pursue in activities'. Travel or trips are emerged as a result of activity participation process. Researchers often explore activities from a variety of perspectives. Damm (1980) has examined the timing of non-work activity. Kitamura et al. (1988) investigated the relationship between activity duration and corresponding travel time. They found that for the case of Osaka, travel time and distance do not affect commuters' work activity durations. Roorda and Miller (2003) found that changes of duration or start time of an activity do not create a ripple effect throughout the entire schedule. Rather, people locally rearrange their plans. Recker et al. (1986) developed STARCHILD (Simulation of Travel /Activity Response to Complex Household Interactive Logistic Decisions), to examine the formation of household travel/activity patterns. They proposed a utility based framework for activity participation process.

\footnotetext{
${ }^{1}$ Corresponding author: anualex@cet.ac.in
} 
The most comprehensive and the only operational computational process model is ALBATROSS developed by Arentze and Timmermans (2000). It is a rule-based system that predicts activity patterns. Bhat and Singh (2000) and Bhat et al. (2004) developed an econometric model called Comprehensive Econometric Microsimulator for Daily Activity-travel Patterns (CEMDEP), in which a comprehensive activity generation-allocation scheduling model was proposed. It considered 'work/ school' as the primary activity of the activity patterns. For prediction of the work/ school duration, it used an econometric hazard model with covariates as socio demographics and work characteristics. By developing FAMOS (Florida Activity Mobility Simulator) Pendyala et al. (2005) proposed a prism constrained simulation approach where work/school are considered to be fixed activities within the daily activity schedule. Roorda et al. (2008) developed a rule-based activity scheduler; TASHA, which also takes the same approach for generating work/ school duration. Eluru et al. (2010) developed a continuous time activity-based microsimulation model of travel demand for the Southern California Association of Governments.

Muralidhar et al. (2006) developed a prototype of time-space diary design which would be user friendly, offers less burden on respondent, and ensures good quality and quantity of data. The study proved that timespace diary has a better performance than conventional travel diary format. Surekha (2009) developed a microsimulation model for activity travel pattern for Tiruchirappalli City, Tamil Nadu, India. Muralidhar et al. (2005) presented a tour-based approach of modelling mode choice of the residents of Mumbai city of India. The study focused on the development of mixed logit model and it is compared to Multinomial Logit Model (MNL). It was found that the performance of the mixed logit model is better than MNL. Sreela et al. (2013) studied the shopping activity travel behaviour of workers in Calicut city, one of the major urban centres in Kerala. This study revealed that the age of the person and household income positively influence the participation in shopping activity, while travel distance and number of non- working adults in household negatively influence shopping. Manoj and Verma (2013) studied the activity-travel behaviour of non-workers in Bangalore city of India. This study modelled the outhome activity participation behaviour of non-workers using a primary activity-travel survey data. Vishnu and Srinivasan (2013) used tours as the fundamental unit of analysis to study the discontinuity in mode choice and independence assumption in trip-based models. The nominal nature of the dependent variable is captured using MNL model.

Saw et al. (2015) developed Activity Based Temporal Trip Generation Models (ABTGM) for primary activities to cover work and educational trips considering fast growing Surat city of Gujarat, India as study area. Reported studies used either econometric models or rule based models for the development of activity based model systems. Due to the complexity and time consumption of rule based models, econometric models have got popularity in activity based modelling. A sequential modelling approach using econometric models was used in all of the studies, in which error in one step will be carried forward to next step, which leads to chances of accumulation of error when the models are used for prediction. Hence an attempt is made in this study to test the suitability of 
unsupervised machine learning technique, Artificial Neural Network, in which a sixteen stage econometric models are replaced with three stage ANN networks. The predictive accuracy of all the output parameters was compared in both the modelling approaches. The study concentrated on the daily activity generation and scheduling of workers.

\section{Methodology and Data Description}

The study area selected is Thiruvananthapuram City, the capital of Kerala, lying in the southernmost part of India. As per 2011 census data, Thiruvananthapuram city consists of $2,42,149$ households with a total population of $9,66,856$. To develop the daily work generation and scheduling model system, an activity travel diary was designed and data were collected via home interview survey by random selection of households. The study used the travel time diary of 9530 members collected from 2521 households. Among this, the working population is $41 \%$, of which, $51 \%$ are male and $49 \%$ are female. Daily work and other activity scheduling models were developed using $80 \%$ of the collected data and the rest $20 \%$ were used for validation. In order to develop the conventional activity based models, an econometric approach used in CEMDAP (Bhat and Singh, 2000) was adopted, in which daily activity schedule models consist of work and other activity generation and scheduling models. Work generation models involve model for finding the out-home work activities and duration and start time of daily work activity. Work scheduling models involve duration and mode of commute before and after work, probability to participate in other activities, duration, time of occurrence and mode of other activities, probability and duration of stop during commute and home stay duration between the out home activities. Econometric models and ANN models were developed in the present study to predict all the above response variables. These models were then validated and prediction accuracies of all the models were compared.

\section{Econometric Modelling Approach}

Using econometric or discrete choice modelling approach, sixteen discrete choice models were developed. This includes eight models for predicting work activity generation and scheduling, four models for other activity of workers and four models for stop level pattern of workers during commute. The independent variables used and their coding are given in Table 1 . The correlation coefficients between the variables are given in Table 2 . It can be observed from the table that the correlation coefficients between all the variables are less than 0.5 which indicates that the variables are not correlated to each other.

\section{Table 1}

Coding of Variables Used

\begin{tabular}{|l|l|}
\hline Independent Variables & Category \\
\hline Household size & 1 to 8 \\
\hline Vehicle Ownership & No vehicle-1, Only Two Wheeler-2, Only Car-3, Both TW and car or more than one car-4 \\
\hline Gender & Male-1, Female-2 \\
\hline Age Group & "18-25"-1, “26-40"-2, “41-55"-3, “56-70"-4 \\
\hline Marital Status & Married-1, Unmarried-2 \\
\hline Employment & Government sector-1, Private sector-2, Self employed-3 \\
\hline Mode of Commute & Walk / Cycle-1, TW-2, Car-3, Bus-4, Train-5 \\
\hline Relationship & Household Head-1, Other-2 \\
\hline Education & Secondary-1, Higher secondary-2, Degree-3, Post Graduate-4 \\
\hline
\end{tabular}


Table 2

Correlation between the Variables

\begin{tabular}{|l|l|l|l|l|l|l|l|l|}
\hline Variables & $\begin{array}{l}\text { Household } \\
\text { Size }\end{array}$ & $\begin{array}{l}\text { Vehicle } \\
\text { Ownership }\end{array}$ & Gender & $\begin{array}{l}\text { Age } \\
\text { Group }\end{array}$ & $\begin{array}{l}\text { Marital } \\
\text { Status }\end{array}$ & Employment & $\begin{array}{l}\text { Whether } \\
\text { head of the } \\
\text { Household }\end{array}$ & Education \\
\hline $\begin{array}{l}\text { Household } \\
\text { Size }\end{array}$ & 1 & 0.159 & 0.014 & -0.084 & 0.087 & -0.038 & -0.199 & -0.06 \\
\hline $\begin{array}{l}\text { Vehicle } \\
\text { Ownership }\end{array}$ & 0.159 & 1 & 0.014 & -0.019 & -0.026 & -0.088 & -0.065 & 0.146 \\
\hline Gender & 0.014 & 0.014 & 1 & 0.016 & 0.012 & 0.3883 & -0.397 & -0.154 \\
\hline Age Group & -0.084 & -0.019 & 0.016 & 1 & -0.251 & 0.354 & 0.319 & 0.069 \\
\hline Marital Status & 0.087 & -0.026 & 0.012 & -0.251 & 1 & 0.012 & -0.237 & -0.253 \\
\hline Employment & -0.038 & -0.088 & 0.383 & 0.354 & 0.012 & 1 & -0.254 & -0.383 \\
\hline $\begin{array}{l}\text { Whether } \\
\text { Head of the } \\
\text { Household }\end{array}$ & -0.199 & -0.065 & -0.397 & 0.319 & -0.237 & -0.255 & 1 & 0.232 \\
\hline Education & -0.06 & 0.146 & -0.154 & 0.069 & -0.253 & -0.383 & 0.232 & 1 \\
\hline
\end{tabular}

\subsection{Work Activity Generation and Scheduling}

Work activity generation part includes models for finding the out-home work activities, how long the individual spend for work and when he/she starts the work i.e.: daily work duration and daily work start time, and finally the duration of commute before and after work activity. The first part is developed using binary logit model since the dependent variable is dichotomous. i.e.; outcome of the model expects the probability of yes/no for an individual to go for out-home work activity. MLR is used for predicting duration or time. Coefficients of the attributes in different models are given in Tables 3 and 4.

Model 1 given in Table 3 shows that the significant factors which cause an individual to be an out-home worker are household size, gender, age group, marital status, whether the person is head of the household and employment. Work start time is modelled as the time of first arrival at the work. The influencing factors of daily work start time are gender, age group, education and daily work duration. The constant term in the model is 519.862 , which indicates that without the independent variables, work start time is $8.20 \mathrm{am}$. This time will vary depending upon the independent variables. Model shows that females come to office early than males and older people start their work early than youngsters. Less educated persons start their work early than highly educated people. If the duration of daily work activity is more, people start their work early. Model 4 gives the daily distance travelled by an individual from home to work place. The average distance travelled by a commuter is $36.285 \mathrm{~km}$ and it will vary depending on the influencing factors namely gender, age group, marital status, employment and work duration. Model shows that daily distance travelled by males are greater than females and youngsters and unmarried persons travel more than older people for work. Daily distance travelled by Govt. sector people are more than private sector followed by self employed. If the work duration is more, daily travelled distance will be less. This may be due to the fact that if the work duration is more, people stay near the work place.

\section{ijtte 80}


The commute duration of a person from home to work place before and after work are also modelled as MLR (Model 5 and 6). The significant variables are found to be vehicle ownership, duration of work activity, employment, mode of commute, age group, gender and start time of work. It is seen that self-employed people take less time for their commute before work, probably because their working place is in the vicinity of their residential areas. If the working duration is more, commute duration is less. This is due to the fact that people stay near the working place, if the working duration is more. As the mode of commute changes from walk or cycle to train, commute duration decreases. Older people take long time for commute compared to younger people. Females are observed to take more commute time than males.

Table 3

Econometric Model System for Work Activity Generation

\begin{tabular}{|c|c|c|c|c|c|c|c|c|c|c|c|}
\hline $\begin{array}{l}\text { Model } \\
\text { No }\end{array}$ & Models & $\begin{array}{l}\text { Model } \\
\text { Form }\end{array}$ & Constant & $\begin{array}{l}\text { Household } \\
\text { Size }\end{array}$ & Gender & $\begin{array}{l}\text { Age } \\
\text { Group }\end{array}$ & $\begin{array}{l}\text { Marital } \\
\text { Status }\end{array}$ & Employment & Education & $\begin{array}{l}\text { Person is } \\
\text { Head of the } \\
\text { Household }\end{array}$ & $\begin{array}{l}\text { Work } \\
\text { Duration }\end{array}$ \\
\hline 1 & $\begin{array}{l}\text { Out-home } \\
\text { Work } \\
\text { Activity }\end{array}$ & $\begin{array}{l}\text { Binary } \\
\text { Logit }\end{array}$ & 14.199 & $\begin{array}{l}0.195^{*} \\
(3.19)\end{array}$ & $\begin{array}{l}-1.129^{*} \\
(-6.29)\end{array}$ & $\begin{array}{l}0.923^{*} \\
(12.00)\end{array}$ & $\begin{array}{l}-3.087^{*} \\
(-13.66)\end{array}$ & $\begin{array}{l}-3.713^{*} \\
(-28.52)\end{array}$ & & $\begin{array}{l}1.390^{*} \\
(7.27)\end{array}$ & \\
\hline 2 & $\begin{array}{l}\text { Work } \\
\text { Duration }\end{array}$ & MLR & 530.402 & & $\begin{array}{l}-36.694^{*} \\
(-6.92)\end{array}$ & $\begin{array}{l}-8.671^{+} \\
(-2.52)\end{array}$ & & $\begin{array}{l}24.033^{*} \\
(11.26)\end{array}$ & $\begin{array}{l}-20.470^{*} \\
(-5.97)\end{array}$ & & \\
\hline 3 & $\begin{array}{l}\text { Work Start } \\
\text { Time }\end{array}$ & MLR & 519.862 & & $\begin{array}{l}-21.598^{*} \\
(-6.55)\end{array}$ & $\begin{array}{l}-4.021^{+} \\
(-2.15)\end{array}$ & & & $\begin{array}{l}8.248^{*} \\
(4.02)\end{array}$ & & $\begin{array}{l}-0.248^{*} \\
(-17.65)\end{array}$ \\
\hline 4 & $\begin{array}{l}\text { Distance } \\
\text { to Work } \\
\text { Place }\end{array}$ & MLR & 36.285 & & $\begin{array}{l}-4.999^{*} \\
(-3.01)\end{array}$ & $\begin{array}{l}-2.994^{*} \\
(-3.00)\end{array}$ & $\begin{array}{l}3.681^{+} \\
(2.08)\end{array}$ & $\begin{array}{l}-3.520^{*} \\
(-4.41)\end{array}$ & & & $\begin{array}{l}-0.020^{*} \\
(-2.85)\end{array}$ \\
\hline
\end{tabular}

${ }^{*}$ Variables at $1 \%$ level of significance + Variables at $5 \%$ level of significance ( ) Values in brackets are $t$ statistics

Table 4

Econometric Model System for Commute Duration for Work Activity

\begin{tabular}{|c|c|c|c|c|c|c|c|c|c|c|c|c|}
\hline $\begin{array}{l}\text { Model } \\
\text { No }\end{array}$ & Models & $\begin{array}{l}\text { Model } \\
\text { Form }\end{array}$ & Constant & Gender & $\begin{array}{l}\text { Age } \\
\text { Group }\end{array}$ & Employment & $\begin{array}{l}\text { Work } \\
\text { Duration }\end{array}$ & $\begin{array}{l}\text { Distance } \\
\text { to Work } \\
\text { Place }\end{array}$ & $\begin{array}{l}\text { Mode of } \\
\text { Commute } \\
\text { Before } \\
\text { Work }\end{array}$ & $\begin{array}{l}\text { Work } \\
\text { Start } \\
\text { Time }\end{array}$ & $\begin{array}{l}\text { WhetherCommute } \\
\text { is After } 5 \text { pm }\end{array}$ & $\begin{array}{l}\text { Mode of } \\
\text { Commute } \\
\text { After Work }\end{array}$ \\
\hline 5 & $\begin{array}{l}\text { Commute } \\
\text { Duration } \\
\text { Before } \\
\text { Work }\end{array}$ & MLR & 25.552 & $\begin{array}{l}1.005^{*} \\
(12.95)\end{array}$ & $\begin{array}{l}1.312^{*} \\
(2.37)\end{array}$ & $\begin{array}{l}-1.757^{*} \\
(-3.70)\end{array}$ & $\begin{array}{l}-0.008^{*} \\
(-1.74)\end{array}$ & $\begin{array}{l}0.008^{*} \\
(8.72)\end{array}$ & $\begin{array}{l}4.398^{*} \\
(17.02)\end{array}$ & $\begin{array}{l}0.015^{+} \\
(2.42)\end{array}$ & & \\
\hline 6 & $\begin{array}{l}\text { Commute } \\
\text { Duration } \\
\text { After work }\end{array}$ & MLR & 2.603 & $\begin{array}{l}0.896^{*} \\
(11.39)\end{array}$ & & $\begin{array}{l}-0.157^{*} \\
(-4.37)\end{array}$ & & $\begin{array}{l}0.008^{*} \\
(8.73)\end{array}$ & & & $\begin{array}{l}0.002^{*} \\
(5.24)\end{array}$ & $\begin{array}{l}0.135^{*} \\
(5.19)\end{array}$ \\
\hline
\end{tabular}

${ }^{*}$ Variables at $1 \%$ level of significance + Variables at $5 \%$ level of significance ( ) Values in brackets are $t$ statistics 
Table 5

Econometric Model System for Mode Choice for Work Activity

\begin{tabular}{|c|c|c|c|c|c|c|c|c|c|c|c|}
\hline $\begin{array}{l}\text { Model } \\
\text { No }\end{array}$ & Models & $\begin{array}{l}\text { Model } \\
\text { Form }\end{array}$ & Constant & $\begin{array}{l}\text { Is the Person } \\
\text { Head of the } \\
\text { Household }\end{array}$ & $\begin{array}{l}\text { Work } \\
\text { Duration }\end{array}$ & \begin{tabular}{|l} 
Work Start \\
Time
\end{tabular} & $\begin{array}{l}\text { Comfort \& } \\
\text { Convenience } \\
\text { of the Mode }\end{array}$ & $\begin{array}{l}\text { Habit } \\
\text { of the } \\
\text { Commuter }\end{array}$ & $\begin{array}{l}\text { Safety of } \\
\text { the Mode }\end{array}$ & $\begin{array}{l}\text { Life Style of } \\
\text { the Commuter }\end{array}$ & $\begin{array}{l}\text { Reliability of } \\
\text { the Mode }\end{array}$ \\
\hline \multirow{5}{*}{7} & \multicolumn{11}{|c|}{ Mode of Commute before Work } \\
\hline & $\mathrm{U}(\mathrm{TW})$ & \multirow{4}{*}{ MNL } & 6.022 & $\begin{array}{l}0.719^{*} \\
(3.5)\end{array}$ & \begin{tabular}{|c}
$-0.003^{*}$ \\
$(-3.73)$ \\
\end{tabular} & $\begin{array}{l}-0.002 \\
(-1.44)\end{array}$ & \begin{tabular}{|l}
$44.837^{*}$ \\
$(9.56)$ \\
\end{tabular} & $\begin{array}{l}22.359^{*} \\
(9.58)\end{array}$ & $\begin{array}{l}0.012 \\
(0.05)\end{array}$ & $\begin{array}{l}1.524^{*} \\
(6.95)\end{array}$ & \begin{tabular}{|l}
$-12.346^{*}$ \\
$(-11.23)$ \\
\end{tabular} \\
\hline & $\mathrm{U}(\mathrm{Car})$ & & -0.219 & $\begin{array}{l}0.920^{*} \\
(3.94)\end{array}$ & $\begin{array}{l}-0.003^{*} \\
(-3.54)\end{array}$ & $\begin{array}{l}-0.004^{*} \\
(-2.87)\end{array}$ & \begin{tabular}{|l}
$37.378^{*}$ \\
$(6.92)$
\end{tabular} & $\begin{array}{l}18.589^{*} \\
(6.93)\end{array}$ & $\begin{array}{l}-0.872^{*} \\
(-3.15)\end{array}$ & $\begin{array}{l}0.837^{*} \\
(3.37)\end{array}$ & \begin{tabular}{|l}
$-13.158^{*}$ \\
$(-9.97)$
\end{tabular} \\
\hline & $\mathrm{U}($ Bus $)$ & & 5.927 & $\begin{array}{l}-0.871^{*} \\
(-3.95)\end{array}$ & $\begin{array}{l}-0.006^{*} \\
(-6.55)\end{array}$ & $\begin{array}{l}-0.002 \\
(-1.63)\end{array}$ & $\begin{array}{l}34.469^{*} \\
(6.71)\end{array}$ & $\begin{array}{l}16.761^{*} \\
(6.57)\end{array}$ & $\begin{array}{l}-0.639+ \\
(-2.43)\end{array}$ & $\begin{array}{l}0.805^{*} \\
(3.37) \\
\end{array}$ & $\begin{array}{l}-9.969^{*} \\
(-8.29)\end{array}$ \\
\hline & $\mathrm{U}($ Train) & & -5.608 & $\begin{array}{l}1.064 \\
(1.45)\end{array}$ & \begin{tabular}{|c|}
-0.004 \\
$(-1.18)$
\end{tabular} & \begin{tabular}{|l|l}
-0.006 \\
$(-1.14)$ \\
\end{tabular} & \begin{tabular}{|l}
$66.064^{*}$ \\
$(3.20)$
\end{tabular} & \begin{tabular}{|l}
$32.209^{*}$ \\
$(3.17)$
\end{tabular} & \begin{tabular}{|c|}
-0.863 \\
$(-1.11)$ \\
\end{tabular} & $\begin{array}{l}1.208 \\
(1.46)\end{array}$ & \begin{tabular}{|l|l}
$-21.583^{*}$ \\
$(-4.06)$ \\
\end{tabular} \\
\hline \multirow{5}{*}{8} & \multicolumn{11}{|c|}{ Mode of Commute after Work } \\
\hline & $\mathrm{U}(\mathrm{TW})$ & \multirow{4}{*}{ MNL } & 5.302 & $\begin{array}{l}0.819^{*} \\
(4.05)\end{array}$ & $\begin{array}{l}-0.003^{*} \\
(-3.76)\end{array}$ & & $\begin{array}{l}41.284^{*} \\
(8.87)\end{array}$ & $\begin{array}{l}20.615^{*} \\
(8.91)\end{array}$ & $\begin{array}{c}-0.0743 \\
(-0.31)\end{array}$ & $\begin{array}{l}1.447^{*} \\
(6.63)\end{array}$ & $\begin{array}{l}-11.275^{*} \\
(10.37)\end{array}$ \\
\hline & $\mathrm{U}(\mathrm{Car})$ & & -1.801 & $\begin{array}{l}0.914^{*} \\
(3.96)\end{array}$ & $\begin{array}{l}-0.003^{*} \\
(-3.22)\end{array}$ & & $\begin{array}{l}35.016^{*} \\
(6.48)\end{array}$ & $\begin{array}{l}17.427^{*} \\
(6.49)\end{array}$ & $\begin{array}{l}-1.041^{*} \\
(-3.77)\end{array}$ & $\begin{array}{l}0.815^{*} \\
(3.28)\end{array}$ & $\begin{array}{l}-12.289^{*} \\
(-9.32)\end{array}$ \\
\hline & U(Bus) & & 4.689 & $\begin{array}{c}-0.842^{*} \\
(-3.87)\end{array}$ & $\begin{array}{l}-0.005^{*} \\
(-6.60)\end{array}$ & & $\begin{array}{l}31.016^{*} \\
(6.06)\end{array}$ & $\begin{array}{l}15.084^{*} \\
(5.93)\end{array}$ & $\begin{array}{c}-0.773^{*} \\
(-2.98)\end{array}$ & $\begin{array}{l}0.700^{*} \\
(2.94)\end{array}$ & $\begin{array}{c}-9.181^{*} \\
(-7.66)\end{array}$ \\
\hline & $\mathrm{U}($ Train) & & -7.217 & $\begin{array}{l}0.751 \\
(1.10)\end{array}$ & $\begin{array}{l}-0.004 \\
(-1.07)\end{array}$ & & $\begin{array}{l}62.624^{*} \\
(3.13)\end{array}$ & $\begin{array}{l}30.667^{*} \\
(3.12)\end{array}$ & $\begin{array}{l}-0.623 \\
(-0.84)\end{array}$ & $\begin{array}{l}1.432^{+} \\
(1.80)\end{array}$ & $\begin{array}{l}-19.462^{*} \\
(-3.79)\end{array}$ \\
\hline
\end{tabular}

${ }^{*}$ Variables at $1 \%$ level of significance + Variables at $5 \%$ level of significance ( ) Values in brackets are $t$ statistics

\subsection{Other Activity of Workers}

Models developed for other activity of workers include probability to participate in other activities, time of occurrence, mode used and duration of other activities. The coefficients of various influencing attributes in all the models are given in Table 6-8. Probability to participate in other activities such as personal business and recreation, shopping and eat out are modelled using MNL (Model 9). The influencing factors for participation in personal business and recreation are gender, marital status, work duration, vehicle ownership and household size. It is observed from the model that males and married persons are more involved in personal business and recreation than females. As work duration increases and vehicle ownership decreases there is less probability to involve in this activity. Probability of shopping depends on household size and work duration. As household size increases and work duration decreases there is more probability of shopping of workers. Males, younger and unmarried people involve more in eat out activity. Gender, age group, marital status and work duration are the influencing factors of eat out activity of workers.

Time of occurrence of other activities of workers was identified as before work, after work and work based. It was also modelled using MNL as shown in Model 10. Base value of the model is taken as 'before work'. Influencing factors of other activity after work are marital status, work duration, purpose of activity, work start time and vehicle 
ownership. It is found that unmarried people prefer to go for other activity after work or during work. As the work duration increases, probability to go for other activity after work decreases and during work increases. As the starting time of work increases, probability of other activity after work and during work decreases than before work. When the vehicle ownership increases, probability of other activity after work increases.

Modes of other activities were identified as walk/cycle/auto, two wheeler, car and bus. The choice of mode for other activity was also modelled with MNL with walk/cycle/auto as the base value and is given in Model 11. Utility of TW are positively influenced by purpose and time of occurrence of activity. Utility of car is positively influenced by gender, age group, purpose and time of occurrence of activity and vehicle ownership. Purpose of activity positively influences and vehicle ownership negatively influences the utility of bus.

Duration of other activity was modelled as MLR as shown in Model 12. The influencing factors are work duration, purpose and mode of activity. Individuals spend more time for personal business and recreation than shopping followed by eat out. It is observed that as work duration increases, duration of other activity decreases and when mode used for the activity changes from walk to bus, duration also increases.

\subsection{Stop Level Pattern during other Activity}

While commuting before and after work, the worker may stop for other activities and it is modelled in this section. Stratification of the collected data is such that about $91.19 \%$ of the workers are not stopping during commute, $7.89 \%$ stop during after work commute and only $0.92 \%$ stop before work commute. Hence the stop level pattern of workers during after work commute is only modelled. The models include probability to stop for other activity, purpose of stop and duration of stop. The coefficients of the models are shown in Table 9. Probability to stop is modelled as binary logit as given in Model 13. Model shows that females and married people have more probability to stop during after work commute. If the mode of commute is bus, lesser the probability to stop and if the commute duration and distance are more, there is higher probability to stop.

Purpose of stop during commute after work are identified as care for children/spouse/ elderly, shopping and personal business and recreation. It is modelled as MNL and with base value as 'care for children/spouse/ elderly'. It is given in Model 14. It is observed that there is more probability for care for children/spouse/elderly than shopping and personal business when the commute duration after work is more. This will be more than shopping if the household size increases. There is more probability of personal business and recreation during commute after work for self employed persons.

Duration of stop is modelled as MLR as shown in Model 15. Model shows that the influencing factors are commute duration after work, distance and purpose of stop. If the commute duration and distance increases, duration of stop will be less. Duration of stop for care for children/ spouse/elderly is less than that of shopping followed by personal business and recreation.

Start time of other activity or the time spent by the individual at home between the work activity and other activity is modelled as MLR. The coefficients of influencing factors 
are given in Table 10. It shows that home stay duration will be less for other activity after work than that before work. If the person reaches the work place by late, obviously home stay duration will be more. If the commute duration and work duration are more home stay duration will be less and as the vehicle ownership increases home stay duration also increases. Females and married people stay more at home between the activities.

\section{Table 6}

Econometric Model System for other Activity Generation of Workers

\begin{tabular}{|c|c|c|c|c|c|c|c|c|c|}
\hline \begin{tabular}{|l|} 
Model \\
No. \\
\end{tabular} & Models & Model & Constant & \begin{tabular}{|l|} 
Household \\
Size
\end{tabular} & Gender & \begin{tabular}{|l} 
Age \\
Group
\end{tabular} & $\begin{array}{l}\text { Marital } \\
\text { Status }\end{array}$ & $\begin{array}{l}\text { Work } \\
\text { Duration }\end{array}$ & \begin{tabular}{|l} 
Vehicle \\
Ownership
\end{tabular} \\
\hline 9 & \multicolumn{9}{|c|}{ Probability of Other Activity } \\
\hline & $\begin{array}{l}\text { U(Personal } \\
\text { Business \& } \\
\text { Recreation) }\end{array}$ & \multirow{3}{*}{ MNL } & 1.264 & $\begin{array}{l}-0.183^{*} \\
(-3.53)\end{array}$ & $\begin{array}{l}-1.520^{*} \\
(-9.24)\end{array}$ & $\begin{array}{l}0.007 \\
(0.08)\end{array}$ & $\begin{array}{l}-0.804^{*} \\
(-4.66)\end{array}$ & $\begin{array}{l}-0.001^{+} \\
(2.14)\end{array}$ & $\begin{array}{l}0.130^{*} \\
(2.59)\end{array}$ \\
\hline & U(Shopping) & & -1.641 & $\begin{array}{l}0.130^{+} \\
(1.75)\end{array}$ & $\begin{array}{l}-0.264 \\
(-1.35) \\
\end{array}$ & $\begin{array}{l}0.198 \\
(1.63)\end{array}$ & $\begin{array}{l}-0.446 \\
(-1.59) \\
\end{array}$ & $\begin{array}{l}-0.002^{+} \\
(-2.18) \\
\end{array}$ & $\begin{array}{l}-0.016 \\
(-0.20)\end{array}$ \\
\hline & $\mathrm{U}$ (Eat out) & & -6.624 & $\begin{array}{l}0.081 \\
(0.94)\end{array}$ & $\begin{array}{l}-1.281^{*} \\
(-3.76)\end{array}$ & $\begin{array}{l}-0.324^{+} \\
(-2.37)\end{array}$ & $\begin{array}{l}0.725^{*} \\
(2.88)\end{array}$ & $\begin{array}{l}0.006^{*} \\
(7.75)\end{array}$ & $\begin{array}{l}0.111 \\
(1.22)\end{array}$ \\
\hline
\end{tabular}

*Variables at $1 \%$ level of significance + Variables at $5 \%$ level of significance ( ) Values in brackets are $t$ statistics

\section{Table 7}

Econometric Model for Time of Occurrence of other Activity Workers

\begin{tabular}{|c|c|c|c|c|c|c|c|c|c|}
\hline \begin{tabular}{|l} 
Model \\
No.
\end{tabular} & Models & Model & Constant & \begin{tabular}{|l|} 
Marital \\
Status
\end{tabular} & Employment & \begin{tabular}{|l|} 
Work \\
duration
\end{tabular} & $\begin{array}{l}\text { Purpose of } \\
\text { Activity }\end{array}$ & $\begin{array}{l}\text { Work Start } \\
\text { Time }\end{array}$ & $\begin{array}{l}\text { Vehicle } \\
\text { ownership }\end{array}$ \\
\hline 10 & \multicolumn{9}{|c|}{ Time of Occurrence of Other Activity } \\
\hline & $\begin{array}{l}\text { U(After } \\
\text { work) }\end{array}$ & MNL & 11.315 & $\begin{array}{l}0.998^{*} \\
(3.14)\end{array}$ & $\begin{array}{l}-0.067 \\
(-0.57) \\
\end{array}$ & $\begin{array}{l}-0.011^{*} \\
(-7.79)\end{array}$ & $\begin{array}{l}2.216^{*} \\
(12.50)\end{array}$ & $\begin{array}{l}-0.021^{*} \\
(-7.92)\end{array}$ & $\begin{array}{l}0.205^{+} \\
(1.80)\end{array}$ \\
\hline & $\begin{array}{l}\mathrm{U} \text { (work } \\
\text { based) }\end{array}$ & MNL & -4.811 & $\begin{array}{l}1.681^{*} \\
(5.29)\end{array}$ & $\begin{array}{l}0.375^{*} \\
(3.13)\end{array}$ & $\begin{array}{l}0.004^{*} \\
(2.94)\end{array}$ & $\begin{array}{l}2.001^{*} \\
(10.62)\end{array}$ & $\begin{array}{l}-0.008^{*} \\
(-3.52)\end{array}$ & $\begin{array}{l}0.126 \\
(1.10)\end{array}$ \\
\hline
\end{tabular}

*Variables at $1 \%$ level of significance +Variables at $5 \%$ level of significance ( ) Values in brackets are $t$ statistics

\section{Table 8}

Econometric Model System for Mode and Duration of other Activity of Workers

\begin{tabular}{|c|c|c|c|c|c|c|c|c|c|c|}
\hline $\begin{array}{l}\text { Model } \\
\text { No. }\end{array}$ & Models & Model & Constant & Gender & $\begin{array}{l}\text { Age } \\
\text { Group }\end{array}$ & $\begin{array}{l}\text { Work } \\
\text { Duration }\end{array}$ & $\begin{array}{l}\text { Purpose of } \\
\text { Activity }\end{array}$ & $\begin{array}{l}\text { Time of } \\
\text { Occurrence } \\
\text { of activity }\end{array}$ & $\begin{array}{l}\text { Vehicle } \\
\text { Ownership }\end{array}$ & $\begin{array}{l}\text { Mode of } \\
\text { Activity }\end{array}$ \\
\hline \multirow[t]{4}{*}{11} & \multicolumn{10}{|c|}{ Mode of Other Activity } \\
\hline & $\mathrm{U}(\mathrm{TW})$ & MNL & -2.523 & $\begin{array}{l}-0.481 \\
(-1.55)\end{array}$ & $\begin{array}{l}-0.172 \\
(-1.28)\end{array}$ & & $\begin{array}{l}0.941^{*} \\
(7.53)\end{array}$ & $\begin{array}{l}0.848^{*} \\
(6.54)\end{array}$ & $\begin{array}{l}0.132 \\
(1.41)\end{array}$ & \\
\hline & $\mathrm{U}(\mathrm{Car})$ & & -9.364 & $\begin{array}{l}0.773^{*} \\
(2.13)\end{array}$ & $\begin{array}{l}0.578^{*} \\
(3.07)\end{array}$ & & $\begin{array}{l}0.887^{*} \\
(4.79)\end{array}$ & $\begin{array}{l}0.906^{*} \\
(4.57)\end{array}$ & $\begin{array}{l}0.664^{*} \\
(4.07)\end{array}$ & \\
\hline & $\mathrm{U}$ (Bus) & & -6.205 & $\begin{array}{l}1.193 \\
(1.41)\end{array}$ & $\begin{array}{l}-0.544 \\
(-0.82)\end{array}$ & & $\begin{array}{l}1.982^{+} \\
(-2.88)\end{array}$ & $\begin{array}{l}0.575 \\
(0.79)\end{array}$ & $\begin{array}{l}-1.043^{+} \\
(-2.03)\end{array}$ & \\
\hline 12 & $\begin{array}{l}\text { Duration } \\
\text { of other } \\
\text { Activity }\end{array}$ & MLR & 108.664 & & & $\begin{array}{l}-0.049^{*} \\
(-2.3)\end{array}$ & $\begin{array}{l}-22.938^{*} \\
(-8.06)\end{array}$ & & & $\begin{array}{l}7.652^{+} \\
(2.76)\end{array}$ \\
\hline
\end{tabular}

${ }^{*}$ Variables at $1 \%$ level of significance +Variables at $5 \%$ level of significance ( ) Values in brackets are $t$ statistics 


\section{Table 9}

Econometric Model System for Stop Level during other Activity of Workers

\begin{tabular}{|c|c|c|c|c|c|c|c|c|c|c|c|}
\hline $\begin{array}{l}\text { Model } \\
\text { No. }\end{array}$ & Models & Model & Constant & Gender & $\begin{array}{l}\text { Marital } \\
\text { Status }\end{array}$ & $\begin{array}{l}\text { Mode of } \\
\text { Commute } \\
\text { After } \\
\text { Work } \\
\end{array}$ & $\begin{array}{l}\text { After work } \\
\text { Commute } \\
\text { Duration }\end{array}$ & Distance & $\begin{array}{l}\text { Household } \\
\text { Size }\end{array}$ & Employment & $\begin{array}{l}\text { Purpose } \\
\text { of Stop }\end{array}$ \\
\hline 13 & $\begin{array}{l}\text { Probability of stop } \\
\text { during Commute } \\
\text { After work }\end{array}$ & $\begin{array}{l}\text { Binary } \\
\text { logit }\end{array}$ & -3.629 & $\begin{array}{l}0.501^{+} \\
(2.51)\end{array}$ & $\begin{array}{l}-0.738^{+} \\
(-2.51)\end{array}$ & $\begin{array}{l}-0.206^{*} \\
(-3.48)\end{array}$ & $\begin{array}{l}0.057^{*} \\
(15.44)\end{array}$ & $\begin{array}{l}0.132^{*} \\
(-7.23)\end{array}$ & & & \\
\hline \multirow[t]{3}{*}{14} & \multicolumn{11}{|c|}{ Purpose of Stop during Commute After work } \\
\hline & $\mathrm{U}($ Stop=shopping $)$ & MNL & 0.488 & & & & $\begin{array}{l}-0.051^{*} \\
(-4.03) \\
\end{array}$ & & \begin{tabular}{|l}
$-0.463^{+}$ \\
$(-2.48)$ \\
\end{tabular} & $\begin{array}{l}0.282 \\
(0.92) \\
\end{array}$ & \\
\hline & $\begin{array}{l}\mathrm{U}(\text { Stop=Personal } \\
\text { business and } \\
\text { recreation })\end{array}$ & MNL & -8.732 & & & & $\begin{array}{l}-0.094^{*} \\
(-5.67)\end{array}$ & & $\begin{array}{l}-0.402 \\
(-1.31)\end{array}$ & $\begin{array}{l}1.341^{*} \\
(2.93)\end{array}$ & \\
\hline 15 & $\begin{array}{l}\text { Duration of stop } \\
\text { during after work } \\
\text { commute }\end{array}$ & MLR & -8.523 & & & & $\begin{array}{l}-0.493^{*} \\
(-12.31)\end{array}$ & $\begin{array}{l}-0.746^{*} \\
(-3.62)\end{array}$ & & & $\begin{array}{l}13.659^{*} \\
(3.84)\end{array}$ \\
\hline
\end{tabular}

${ }^{*}$ Variables at $1 \%$ level of significance +Variables at $5 \%$ level of significance ( ) Values in brackets are $t$ statistics

Table 10

Econometric Model for Start Time or other Activity

\begin{tabular}{|l|l|l|}
\hline Model No. & \multicolumn{1}{l|}{$\mathbf{1 6}$} \\
\hline Models & \multicolumn{2}{l|}{ Start time of other activity } \\
\hline Model Form & MLR \\
\hline Constant & 28.304 \\
\hline Time of other activity & $-42.929^{*}$ & $(-5.72)$ \\
\hline Work start time & $0.323^{*}$ & -7.34 \\
\hline Commute duration before work & $-0.558^{*}$ & $(-3.86)$ \\
\hline Purpose of activity & $11.765^{*}$ & -4.39 \\
\hline Work duration & $-0.113^{*}$ & $(-3.72)$ \\
\hline Household size & $-10.092^{*}$ & $(-4.27)$ \\
\hline Vehicle ownership & $7.352^{*}$ & -2.9 \\
\hline Gender & $20.888^{+}$ & -2.53 \\
\hline Duration of other activity & $-0.143^{*}$ & $(-2.59)$ \\
\hline Mode of commute before work & $-3.853^{+}$ & $(-2.04)$ \\
\hline Marital status & $-26.284^{*}$ & $(-2.98)$ \\
\hline Age Group & $-9.576^{+}$ & $(-2.52)$ \\
\hline Employment & $5.481^{+}$ & -1.98 \\
\hline
\end{tabular}

${ }^{*}$ Variables at $1 \%$ level of significance

+ Variables at $5 \%$ level of significance

() Values in brackets are t statistics

\section{Neural Network Modelling}

Artificial Neural Network as a computing system is made up of a number of simple, and highly interconnected processing elements, which processes information by its dynamic state response to external inputs. The multi-layer feed-forward network, the 
most popular of the much architecture currently available, was used in this study. The network was trained using an error back propagation training algorithm. This algorithm adjusts the connection weights according to the back propagated error computed between the observed and the estimated results. This is an unsupervised learning procedure that attempts to minimise the error between the desired and the predicted outputs. The networks used in this study consisted of four layers: one input layer, two hidden layers and one output layer. The sixteen stage econometric models were replaced with three stage neural networks as shown in Table 11 .

\section{Table 11}

ANN Networks

\begin{tabular}{|c|c|c|}
\hline Model No. & Econometric Models & ANN Networks \\
\hline 1 & Out home work activity (Yes/ No) & \multirow{4}{*}{ ANN Network 1} \\
\hline 2 & Work duration & \\
\hline 3 & Work Start time & \\
\hline 4 & Distance to the Work place & \\
\hline 5 & Duration of Commute before work & \multirow{7}{*}{ ANN Network 2} \\
\hline 6 & Duration of Commute after work & \\
\hline 7 & Mode of commute before work & \\
\hline 8 & Mode of commute after work & \\
\hline 9 & Probability and Purpose of other activity & \\
\hline 10 & Probability of stop during commute after work & \\
\hline 11 & Purpose of stop during commute after work & \\
\hline 12 & Time of other activity & \multirow{5}{*}{ ANN Network 3} \\
\hline 13 & Mode of other activity & \\
\hline 14 & Duration of other activity & \\
\hline 15 & $\begin{array}{l}\text { Other activity start time or home stay duration between the out home } \\
\text { activities }\end{array}$ & \\
\hline 16 & Duration of stop after work & \\
\hline
\end{tabular}

First network was for work activity generation, second network for work activity scheduling and third network for other activity of workers. Each network is discussed in detail in the following sections.

\subsection{Neural Network for Work Activity Generation}

This network consisted of four layers: one input layer of eight neurons (one for each input variable), two hidden layers of twenty neurons (it is the number which gives the best prediction result) and one output layer of four neurons which are the output variables (Fig. 1). The input variables used are gender, age group, education, marital status, employment, vehicle ownership and whether the individual is head of the household. The output variables are whether the individual perform out home work activity, and if so, work duration, work start time and distance to work place. Best training performance of the network was observed at 1000 epoch (Fig. 2). 


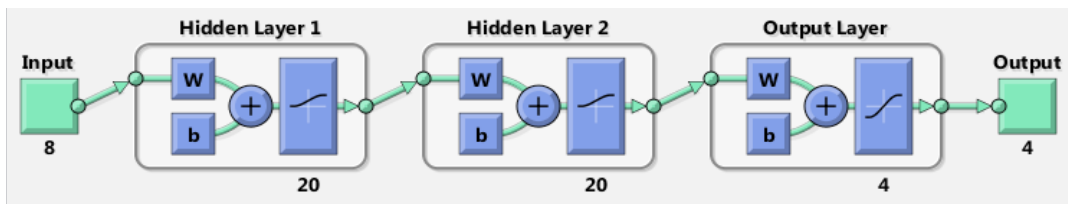

Fig. 1.

Neural Network for Work Activity Generation

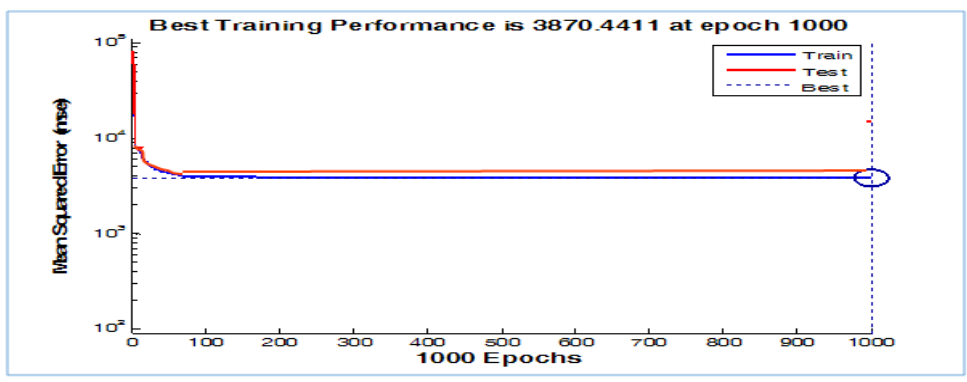

Fig. 2.

Training Performance of Neural Network for Work Activity Generation

\subsection{Neural Network for Work Activity Scheduling}

This network also consists of four layers: one input layer of fifteen neurons as input variables, two hidden layers of twenty neurons and one output layer of six neurons as the output variables (Fig. 3). The input variables used are gender, age group, education, marital status, employment, vehicle ownership, whether the individual is head of the household, work duration, work start time, distance to work place from home, comfort and convenience of the mode, habit of the commuter, safety of the mode, life style of the commuter and reliability of the mode. The output variables are commute mode and duration before and after work, purpose of stop and other activity of workers. The network shows best training performance at 418 epochs (Fig. 4).

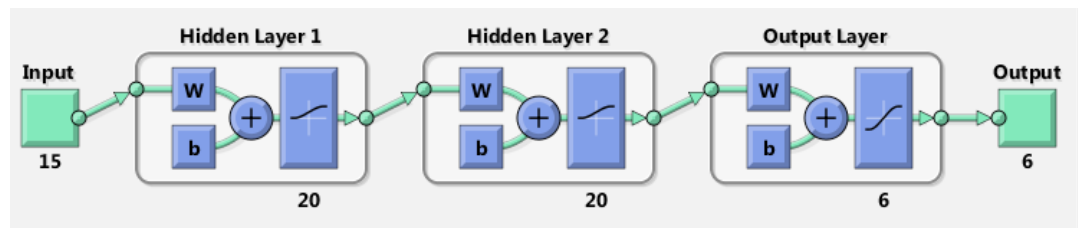

Fig. 3.

Neural Network for Work Activity Scheduling 


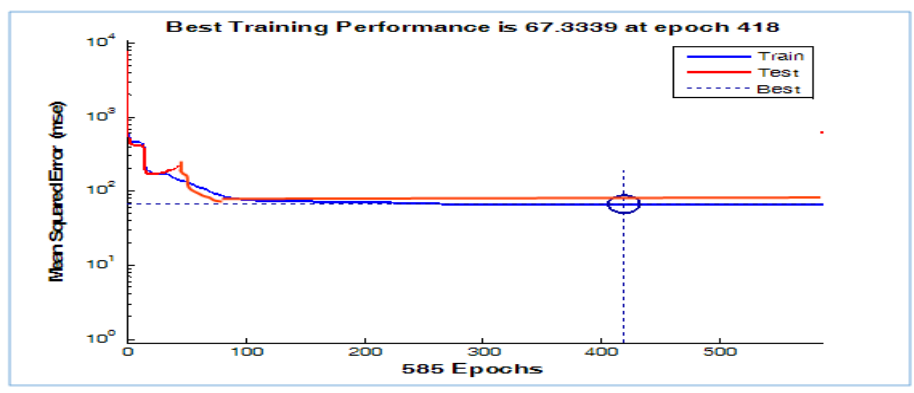

Fig. 4.

Training Performance of Neural Network for Work Activity Scheduling

\subsection{Neural Network for other Activity of Workers}

This network was developed with four layers: one input layer of fifteen neurons as input variables, two hidden layers of twenty neurons and one output layer of five neurons as the output variables (Fig. 5). The input variables used are gender, age group, education, marital status, employment, vehicle ownership, whether the individual is head of the household, work duration, work start time, distance to work place from home, mode and duration of commute before and after work, purpose of other activity and purpose of stop during commute. The output variables are mode of commute, time of occurrence and duration of other activity, duration of stop during commute and duration of home stay between the activities of workers. The best training performance of the network was observed at 765 epoch (Fig. 6).

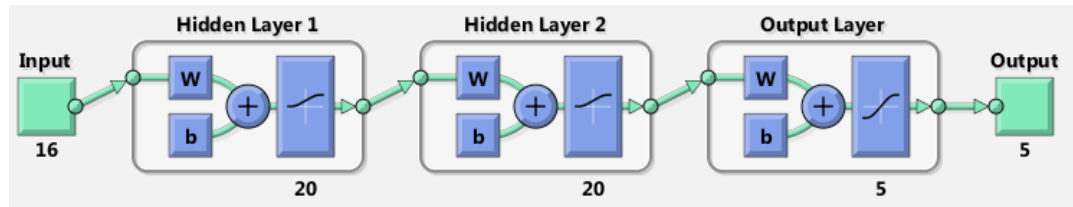

Fig. 5.

Neural Network for other Activity of Workers

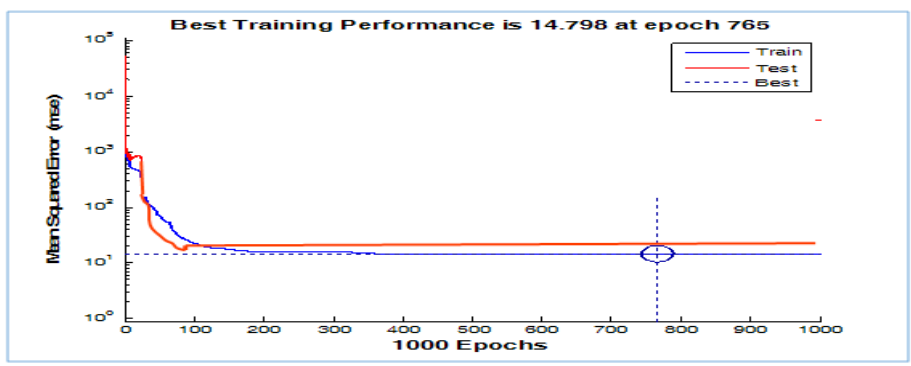

Fig. 6.

Training Performance of Neural Network for other Activity of Workers 


\section{Validation of the Models}

The models discussed in the previous sections can be used for finding out the generation of work and other activity of workers, timing of out home activities and the mode used for each activity of each individual. Both econometric and neural network models were applied to $20 \%$ of the collected data. Results of response variables for each individual were compared between both approaches. The response variables obtained for MNL and Binary logit models were compared as truly predicted and wrongly predicted and the percentage error is calculated. Response variables obtained from MLR models are compared with the observed values and Relative Root Mean Square Error (RRMSE) was calculated. Percentage errors of all the output variables in both models were also compared. Results are shown in Table 12.

Table 12

Comparison of the Models

\begin{tabular}{|c|c|c|c|c|c|c|c|}
\hline \multirow[b]{2}{*}{ Response Variables } & \multicolumn{3}{|c|}{ Econometric Models } & \multicolumn{3}{|c|}{ ANN Networks } & \multirow[b]{2}{*}{$\begin{array}{l}\text { Decrease in } \\
\text { Error }(\%)\end{array}$} \\
\hline & \begin{tabular}{|l|} 
Truly \\
Predicted
\end{tabular} & $\begin{array}{l}\text { Wrongly } \\
\text { Predicted }\end{array}$ & \% Error & $\begin{array}{l}\text { Truly } \\
\text { Predicted }\end{array}$ & $\begin{array}{l}\text { Wrongly } \\
\text { Predicted }\end{array}$ & $\%$ Error & \\
\hline $\begin{array}{l}\text { Out home work activity } \\
\text { (Yes/No) }\end{array}$ & 1667 & 239 & 12.54 & 1861 & 45 & 2.36 & 10.18 \\
\hline Work duration & & & 25.84 & & & 13.38 & 12.46 \\
\hline Work start time & & & 22.71 & & & 7.27 & 15.44 \\
\hline Distance to the work place & & & 18.96 & & & 11.89 & 7.07 \\
\hline $\begin{array}{l}\text { Mode of commute before } \\
\text { work }\end{array}$ & 940 & 448 & 32.29 & 1192 & 196 & 14.1 & 18.19 \\
\hline Mode of commute after work & 955 & 433 & 31.19 & 1201 & 187 & 13.48 & 17.71 \\
\hline $\begin{array}{l}\text { Duration of commute before } \\
\text { work }\end{array}$ & & & 31.74 & & & 14.03 & 17.71 \\
\hline $\begin{array}{l}\text { Duration of commute after } \\
\text { work }\end{array}$ & & & 35.01 & & & 16.86 & 18.15 \\
\hline $\begin{array}{l}\text { Probability and purpose of } \\
\text { other activity }\end{array}$ & 992 & 396 & 28.53 & 1133 & 255 & 18.34 & 10.19 \\
\hline $\begin{array}{l}\text { Probability of stop during } \\
\text { commute after work }\end{array}$ & 1284 & 104 & 7.52 & 1318 & 70 & 5.02 & 2.5 \\
\hline $\begin{array}{l}\text { Purpose of stop during } \\
\text { commute after work }\end{array}$ & 172 & 19 & 10.00 & 176 & 15 & 7.78 & 2.22 \\
\hline $\begin{array}{l}\text { Time of occurrence of other } \\
\text { activity }\end{array}$ & 274 & 126 & 31.52 & 359 & 41 & 10.33 & 21.19 \\
\hline Mode of other activity & 241 & 159 & 39.67 & 350 & 50 & 12.5 & 27.17 \\
\hline Duration of other activity & & & 22.1 & & & 6.18 & 15.92 \\
\hline Duration of stop after work & & & 22.12 & & & 7.12 & 15 \\
\hline Other activity start time & & & 12.89 & & & 5.84 & 7.05 \\
\hline
\end{tabular}

It can be seen that the accuracy of all the ANN models are greater than econometric models. This is due to the learning ability of ANN compared to the econometric models.
It can actually learn from observing data sets. Hence ANN is used as a random function approximation tool. These types of tools help estimate the most cost-effective and 
ideal methods for arriving at solutions while defining computing functions or distributions. It takes data samples rather than entire data sets to arrive at solutions, which saves both time and money.

\section{Conclusion}

Travel demand models are used to replicate the real world transportation system and to predict the future travel demand. A behavioural oriented approach in travel demand analysis is provided by activity based travel demand modelling and it provides a better understanding of the travel behaviour of an individual, but they are very complex and demand more data. The main application of this approach lies in the traffic control policies. The activity travel demand models can vary depending upon the type of data as well as the purpose of the study. There are so many activity generation model systems for developed countries, which are partially and fully operationalized. For a developing country like India, activity based planning process is still at the infant stage due to its complexity and lack of readily available micro data of individuals.

This study is concentrated on the important part of the activity based travel demand modelling, which is daily work activity generation. Thiruvananthapuram, which is the capital city of Kerala in India is selected as the study area for developing the models. A daily activity schedule model system for workers was developed in this study based on two approaches. The first approach was conventional econometric modelling which is sequential modelling. The second approach was ANN modelling, which is simultaneous modelling. Sixteen stage econometric models were replaced with three stage ANN models in this study. Hence the error accumulation in sequential modelling approach is reduced in this new simultaneous modelling approach. Models in both approaches were validated using $20 \%$ of the data and the percentage error was calculated for both approaches. It is seen that ANN models are more predictive than discrete choice models. The decrease in percentage error ranges from $2.22 \%$ to $27.17 \%$ in the case of ANN models. Hence it can be concluded that the conventional econometric models if replaced with ANN models in activity based modelling will provide better results.

\section{Acknowledgement}

The authors are grateful to Kerala State Council for Science Technology and Environment (KSCSTE) for funding the project.

\section{References}

Arentze, T.A.; Timmermans, H. 2000. ALBATROSS - A learning based transportation oriented simulation system. In Proceedings of the TRB Conference 2000, USA, Issue No. 1706, 136-144.

Bhat, C.R.; Guo, J.Y.; Srinivasan, S.; Sivakumar, A. 2004. Comprehensive Econometric Microsimulator for Daily Activity-Travel Patterns, Transportation Research Record: Journal of the Transportation Research Board, No. 1894, TRB, National Research Council, Washington, D.C., 57-66.

Bhat, C.R.; Singh, S.K. 2000. A Comprehensive Daily Activity-Travel Generation Model System for Workers, Transportation Research Part A: Policy and Practice, 34(1): $1-22$.

Damm, D. 1980. Interdependencies in activity behavior, Transportation Research Record, 750. 
Eluru, N.; Pinjari, A.R.; Pendyala, R.M.; Bhat, C.R. 2010. An econometric Multi-Dimensional Choice Model of Activity-Travel Behaviour, Transportation Letters: The International Journal of Transportation Research, 2(4): 217-230.

Kitamura, R. 1988. An evaluation of activity-based travel analysis, Transportation, 15(1): 9-34.

Manoj, M.; Verma, A. 2013. Analysis and Modelling of Activity-Travel Behaviour of Nonworkersfrom a City of Developing Country, India. In Proceedings of the 2 nd Conference of Transportation Research Group of India (2nd CTRG), Procedia-Social and Behavioral Sciences, 104(2013): 621-629.

Muralidhar, B.; Mathew, T.V.; Dhingra, S.L. 2005. Development of a Mixed Logit Model to Tour Mode Choice for an Urban Region. In Proceedings of International Conference CUPUM 2005, London U.K.

Muralidhar, B.; Mathew, T.V.; Dhingra, S.L. 2006. Prototype Time-Space Diary Design and Administration for a Developing Country, Journal of Transportation Engineering, ASCE, 132(6): 489-498.

Pendyala, R.M.; Kitamura, R.; Kikuchi, A.; Yamamoto, T.; Fujii, S. 2005. Florida Activity Mobility Simulator - Overview and Preliminary Validation Results, Transportation Research Record: Journal of the Transportation Research Board, No. 1921, Transportation Research Board of the National Academies, Washington, D.C., 123-130.

Recker, W.W.; McNally, M.G.; Root, G.S. 1986. A model of complex travel behaviour: part I - theoretical development, Transportation Research Part A, 20A(4): 307-318.
Roorda, M.J.; Miller, E.J. 2003. A Prototype Model of Household Activity/Travel Scheduling. Presented at the Transportation Research Board Annual Meeting.

Roorda, M.J.; Miller, E.J.; Habib, K.M.N. 2008. Validation of TASHA: A 24-h activity scheduling microsilulation model, Transportation Research Part A, 42(2): 360-375.

Saw, K.; Katti, B.K.; Joshi, G.K. 2015. AB temporal trip generation modelling for primary activities: a case study of fast growing metropolitan city, International Journal for Traffic and Transport Engineering, 2015, 5(2): 120-133.

Sreela, P.K.; Melayil, S.; Anjaneyulu, M.V.L.R. 2013. Modeling of Shopping Participation and Duration of Workers in Calicu. In Proceedings of the 2nd Conference of Transportation Research Group of India (2nd CTRG), Procedia - Social and Behavioral Sciences, 104(2013): 543-552.

Surekha, N. 2009. Microsimulation of Activity-Travel Pattern for Tiruchirappalli City, M. Tech Thesis at NIT Tiruchirappalli.

Vishnu, B.; Srinivasan, K.K. 2013. Tour-based departure time models for work and non-work tours ofworkers. In Proceedings of the 2 nd Conference of Transportation Research Group of India (2nd CTRG), Procedia-Social and Behavioral Sciences, 104(2013): 630-639. 